\title{
PERKEMBANGAN HUKUM SEKTOR JASA KEUANGAN DALAM UPAYA PERCEPATAN PERTUMBUHAN EKONOMI NASIONAL
}

\author{
Tri Handayani \\ Lastuti Abubakar \\ Fakultas Hukum Universitas Padjadjaran \\ E-mail: tri.handayani@unpad.ac.id
}

\begin{abstract}
Indonesia's financial services sector shows a rapid development in line with changes in the regional and global sector. Taking a role in promoting the acceleration of national economic growth, financial services sector is directed to optimally play a role in stability of the financial system as a foundation for sustainable development, and realizing the financial independence of the community and supporting efforts to increase equity in Development (inclusive). This research uses normative juridical approach with analytical descriptive research specification. Data were analyzed by qualitative juridical. Based on the results of the research, the regulation in the financial services sector is growing rapidly as a result of regional and global demands, especially facing the ASEAN Banking Integration Framework (ABIF). Legal developments in the financial services sector are reflected in regulatory changes on institutional, service and product aspects as well as dispute resolution. There is still a need for legal reform that can provide a solid legal basis for the financial services sector, namely civil law reform and banking law.
\end{abstract}

\section{Kata Kunci: Ekonomi Nasional, Perkembangan Hukum, Sektor Jasa Keuangan}

\section{A. Latar Belakang}

Merujuk pada data yang dikeluarkan oleh Badan Pusat Statistik (BPS) awal Februari tahun ini, sektor jasa keuangan menjadi sektor dengan pertumbuhan tertinggi dibandingkan dengan sektor jasa lainnya dalam pertumbuhan ekonomi tahun 2016. Eko Listiyanto (http://wartaekonomi.co.id., diakses tanggal 26 Juli 2017), menjelaskan bahwa pertumbuhan sektor jasa keuangan terus meningkat dalam 3 tahun terakhir, khususnya sektor perbankan dan asuransi. Secara umum, sektor jasa keuangan dan asuransi berkontribusi 4,20\% pada tahun 2016 atau naik dibandingkan tahun lalu sebesar 4,3\% dan 3,86\% di tahun 2014. Data BPS 
menunjukkan bahwa sektor perbankan menguasai 60-70\% dari keseluruhan sektor jasa keuangan. Dalam laporan Perekonomian Indonesia 2015, Bank Indonesia selaku otoritas perbankan, memperkirakan ekonomi Indonesia pada tahun 2016 tumbuh antara 5,2 \%-5,6 \% dengan inflasi $4+/-1 \%$ dimana defisit transaksi berjalan sedikit meningkat, tetapi tetap aman dan mempunyai struktur yang lebih sehat, dan untuk prospek jangka menengah pada tahun 2020 diperkirakan inflasi turun menjadi 3,5 +/- $1 \%$ dengan pertumbuhan ekonomi diperkirakan akan naik menjadi 6,3-6,8 \% dengan defisit transaksi berjalan di bawah batas aman $3 \%$ dari PDB dengan struktur yang lebih sehat (Bank Indonesia, 2016: 252). Berdasarkan data di atas, dapat dilihat bahwa perekonomian Indonesia mengalami pertumbuhan ke arah yang lebih baik. Hal ini tidak dapat dilepaskan dari berbagai kebijakan yang dituangkan dalam regulasi yang antisipatif terhadap perkembangan ekonomi global dan peran otoritas sektor jasa keuangan, baik Otoritas Jasa Keuangan maupun Bank Indonesia. Kedua otoritas ini, khususnya Bank Indonesia sebagai otoritas di bidang macroprudential berperan penting dalam menentukan arah kebijakan untuk menghadapi tantangan global dan domestik untuk memacu pertumbuhan ekonomi nasional.

Tantangan global bersumber dari pertumbuhan ekonomi global yang masih belum cukup kuat dan berlanjutnya penurunan harga komoditas dunia, dan walaupun pertumbuhan ekonomi global diperkirakan membaik, tetapi masih terdapat risiko pertumbuhan tersebut menjadi lebih rendah sejalan perekonomian AS yang belum cukup solid dan perlambatan ekonomi Tiongkok. Tantangan global lainnya adalah mulai berlakunya Masyarakat Ekonomi Asean (MEA), yang memberikan peluang dan tantangan ke depan. Peluang Indonesia cukup besar menjadi basis produksi untuk menjadi pemasok dalam rantai nilai Asean dan global. Diharapkan dengan dihapuskannya tarif (perdagangan bebas), produk domestik berpeluang memenangkan pasar dari produk negara lain dengan catatan peluang ini dipersiapkan dengan baik dari berbagai aspek, termasuk aspek regulasi.

Di sisi domestik, perekonomian Indonesia ke depan dihadapkan pada tantangan berupa 4 (empat) permasalahan struktural domestik dengan mengacu 
pada arah kebijakan pembangunan nasional, dimana terdapat 4 (empat) pilar yang menjadi prioritas untuk dibenahi yaitu: (1) pencapaian ketahanan pangan; energi, dan air; (2) daya saing maritim, industri, dan pariwisata; (3) pembiayaan pembangunan yang berkesinambungan, dan (4) ekonomi inklusif. Salah satu prasyarat agar terciptanya pertumbuhan ekonomi yang berkelanjutan adalah stabilitas makro ekonomi dan sistem keuangan (Bank Indonesia, 2016: 259).

Terkait dengan fundamental perekonomian Indonesia, tantangan lainnya adalah terbatasnya daya dukung pembiayaan jangka panjang dari sektor keuangan formal dalam pembangunan nasional. Sektor jasa keuangan Indonesia masih di dominasi oleh perbankan yang memiliki basis sumber dana jangka pendek, sehingga memilik risiko mismatch. Sumber-sumber pembiayaan jangka panjang melalui pasar modal masih terbatas, bahkan masih tertinggal dibanding kawasan Asean lainnya. Tantangan berikutnya bagi pembiayaan pembangunan nasional adalah pentingnya mendorong aliran masuk modal asing dalam bentuk penanaman modal langsung (foreign direct investment), terutama pada industri berorientasi ekspor, yang tidak hanya merupakan sumber pembiayaan yang penting, tetapi juga meningkatkan daya saing industri dimaksud dalam rantai perdagangan internasional (Laporan Perekonomian Indonesia, 2015).

Permasalahan utama yang menghambat masuknya modal asing ke Indonesia antara lain karena keterbatasan infrastruktur dan lambatnya proses perijinan. Apabila dilihat tantangan-tantangan yang dihadapi dalam pembangunan ekonomi nasional, maka tidak dapat dilepaskan dari fungsi sektor jasa keuangan Indonesia. Hal ini mendorong Otoritas Jasa Keuangan (OJK) untuk menerbitkan Master Plan Sektor Jasa Keuangan Indonesia (MPSJKI) 2015-2019 yang memiliki 3 (tiga) fokus utama, yaitu: mengoptimalkan peran sektor jasa keuangan dalam mendukung percepatan pertumbuhan ekonomi nasional (kontributif), menjaga stabilitas sistem keuangan sebagai landasan bagi pembangunan yang berkelanjutan (stabil), dan mewujudkan kemandirian finansial masyarakat serta mendukung upaya peningkatan pemerataan dalam pembangunan (inklusif). Penyusunan MPSJKI ini juga telah diselaraskan dengan program pembangunan ekonomi nasional yang telah dicanangkan oleh Pemerintah melalui Rencana 
Pembangunan Jangka Panjang Nasional (RPJPN) 2005-2025 dan Rencana Pembangunan Jangka Menengah Nasional (RPJMN) 2015-2019.

Arah pengembangan sektor jasa keuangan nasional ini selanjutnya dijabarkan dalam program-program inisiatif yang lebih rinci dalam roadmap pengembangan masing-masing sektor jasa keuangan. Dalam Buku II RPJMN 2015-2019 Bab 3 tentang Pembangunan Ekonomi menyatakan bahwa pembangunan sektor keuangan difokuskan kepada ketahanan dan daya saing sektor keuangan. Peningkatan ketahanan dan daya saing sektor keuangan ini bertujuan untuk meningkatkan kesejahteraan rakyat melalui pencapaian stabilitas sektor keuangan yang berkontribusi pada stabilitas ekonomi, pertumbuhan ekonomi berkelanjutan, serta pembangunan ekonomi inklusif dan berkeadilan. Selanjutnya, berkaitan dengan fungsi hukum, berbagai arah kebijakan dan strategi yang dicanangkan dalam kerangka pikir Rencana Pembangunan Hukum 20152019 diharapkan dapat membantu perwujudan sasaran utama yakni, meningkatkan daya saing perekonomian. Dengan demikian, jelas bahwa hukum berfungsi untuk memastikan bahwa pembangunan ekonomi nasional berjalan sebagaimana yang diharapkan.

Secara khusus, regulasi sektor jasa keuangan berkembang pesat seiring dengan perkembangan sektor jasa keuangan, baik meliputi kelembagaan, produk dan layanan serta transaksi yang berkembang guna mengikuti perkembangan global. Peran strategis OJK dalam pengaturan dan pengawasan sektor jasa keuangan secara terintegrasi dan Bank Indonesia sebagai otoritas moneter sangat penting untuk mempercepat pertumbuhan ekonomi nasional, dan oleh sebab itu perlu penelitian untuk memetakan perkembangan regulasi sektor jasa keuangan sebagai upaya untuk mempercepat pertumbuhan ekonomi nasional.

\section{B. Metode Penelitian}

Penelitian bersifat deskriptif analitis, yaitu membuat pencandraan secara sistematis, faktual dan akurat mengani fakta-fakta. Oleh karena itu penelitian ini sifatnya mengkaji dan memaparkan perkembangan regulasi sektor jasa keuangan sebagai salah upaya untuk mendorong percepatan pertumbuhan perekonomian 
nasional dari perspektif hukum. Metode pendekatan yang digunakan adalah pendekatan yuridis normatif, dengan menekankan pada kajian terhadap data sekunder berupa bahan hukum primer yaitu peraturan perundang-undangan, bahan hukum sekunder baik jurnal maupun hasil penelitian sebelumnya dan bahan hukum tersier. Selanjutnya, data yang diperoleh baik berupa data sekunder dianalisis secara yuridis kualitatif.

\section{Hasil Penelitian dan Analisis}

\section{Peran sektor jasa keuangan dalam mempercepat pertumbuhan ekonomi nasional}

Arah Pengembangan Sektor Jasa Keuangan Indonesia dimuat dalam Master Plan Sektor Jasa Keuangan Indonesia (Otoritas Jasa Keuangan: 34), yanag dijabarkan sebagai berikut

a. Mengoptimalkan peran SJK dalam mendukung percepatan pertumbuhan ekonomi nasional. Ke depan, SJK diarahkan untuk semakin kontributif dalam mendorong kegiatan ekonomi masyarakat. Dengan optimalisasi perannya dalam pembangunan ekonomi, SJK diarahkan untuk dapat meningkatkan kapasitas perekonomian sehingga mencapai pertumbuhan yang lebih tinggi dan berkualitas.

b. Menjaga stabilitas sistem keuangan sebagai landasan bagi pembangunan yang berkelanjutan. Sektor jasa keuangan diarahkan untuk memiliki daya tahan yang memadai dalam mengantisipasi goncangan yang dapat muncul dari lingkungan domestik maupun eksternal. Stabilitas sistem keuangan ini juga merupakan landasan bagi proses pertumbuhan yang sehat dan berkelanjutan.

c. Mewujudkan kemandirian finansial masyarakat, serta mendukung upaya peningkatan pemerataan dalam pembangunan. Hasil akhir dari pembangunan ekonomi nasional seyogyanya dapat memberikan manfaat bagi peningkatan kesejahteraan seluruh masyarakat, serta mengatasi ketimpangan dalam pembangunan nasional. untuk mencapai hal tesrebut, SJK diarahkan untuk dapat mengambil peran dalam mewujudkan kemandirian finansial masyarakat melalui program keuangan yang inklusif.

Ditengah siklus pertumbuhan ekonomi yang melambat, serta situasi global yang kurang menggembirakan, sektor jasa keuangan dapat memainkan peranan penting untuk mempercepat pertumbuhan ekonomi. Apabila dimanfaatkan secara optimal, sektor jasa keuangan dapat meningkatkan kapasitas perekonomian, sehingga tercapai pertumbuhan yang lebih tinggi dan lebih berkualitas, sedangkan pertumbuhan ekonomi yang lebih tinggi merupakan keharusan agar dapat 
menyerap tambahan tenaga kerja dan meningkatkan taraf hidup masyarakat. OJK akan terus mengupayakan peningkatan peran sektor jasa keuangan dalam mempercepat pertumbuhan ekonomi nasional. Inisiatif yang akan ditempuh mencakup berbagai aspek, dari penguatan kelembagaan sektor jasa keuangan hingga penyesuaian peraturan untuk menciptakan iklim yang kondusif bagi peningkatan proses intermediasi. Upaya untuk mendukung percepatan pertumbuhan ekonomi harus tetap berlangsung tanpa menimbulkan gangguan pada stabilitas sistem keuangan secara keseluruhan. Untuk itu, sektor jasa keuangan harus memiliki daya tahan memadai dalam mengantisipasi goncangan yang dapat muncul dari lingkungan domestik maupun eksternal.

Ke tiga arah pengembangan SJK di atas perlu di dukung oleh kesiapan sumberdaya manusia, baik kuantitas maupun kualitas dan pemanfaatan teknologi informasi. Diharapkan pada tahun 2019 SJK berperan dalam transformasi ekonomi nasional dengan produktivitas dan nilai tambah yang tinggi, pertumbuhan ekonomi yang tinggi dan berkelanjutan (sustainable/green financing), serta terciptanya era digitalisasi sektor jasa keuangan. Berkenaan dengan peningkatan sumber daya manusia di sektor jasa keuangan, OJK menerbitkan regulasi dan kebijakan yang mewajibkan sumber daya manusia di sektor jasa keuangan memiliki kompetensi dan profesionalisme. Khusus untuk profesi penunjang pasar modal yaitu akuntan publik, konsultan hukum, penilai dan notaris, Otoritas Jasa Keuangan telah menerbitkan serangkaian aturan yang mewajibkan persyaratan dan independensi profesi penunjang pasar modal. demikian juga halnya dengan industri keuangan non bank, seperti asuransi. Perusahaan asuransi wajib memiliki penilai atau agen yang bersertifikasi untuk menjamin independensi dan profesionalisme mereka.

Dalam perkembangannya, Otoritas Jasa Keuangan dari waktu ke waktu berupaya mewujudkan tujuan pengembangan SJK Indonesia. Dalam hal pemanfaatan teknologi informasi, sektor jasa keuangan, khususnya Pasar Modal telah memanfaatkan teknologi informasi untuk mewujudkan pasar modal yang teratur wajar dan efisien. Sejak pertengahan tahun 2000, pasar modal Indonesia telah memperkenalkan scripless trading system atau perdagangan tanpa warkat 
yang berbasis teknologi informasi. Perdagangan di pasar modal meningkat dari sisi kuantitas dan optimal dalam memberikan kepastian dan perlindungan hukum bagi para investor. Konsekuensi yuridisnya, regulasi di pasar modal mengalami perubahan yang signifikan. Pasar Modal Indonesia telah berkontribusi secara signifikan terhadap pembaruan hukum, khususnya Hukum Perdata dan Hukum Pembuktian. Transaksi-transaksi di pasar modal banyak mengadopsi perjanjian dalam sistem common law, yang semula belum dikenal dalam praktik bisnis di Indonesia. Perkembangan instrumen pasar modal yang mengikuti standar internasional telah memperkaya aspek kebendaan dalam sistem hukum benda. Meskipun terdapat hambatan-hambatan yuridis, tetapi Pasar Modal Indonesia termasuk lembaga yang mendorong percepatan dalam pembaruan hukum perdata Indonesia. Scripless trading system pun telah memperkaya alat bukti dalam sistem hukum acara, dengan mengakui dokumen elektronik sebagai dokumen hukum yang dapat diterima sebagai alat bukti, jauh sebelum Undang-undang Nomor 11 Tahun 2008 tentang Informasi dan Transaksi Elektronik (UU ITE) diberlakukan. Pasar Modal Syariah telah memperkenalkan Sistem Online Trading Syariah (SOTS), yaitu sistem yang disiapkan oleh Perusahaan Efek Anggota Bursa untuk digunakan oleh investor untuk bertransaksi pada saham-saham yang masuk dalam Daftar Efek Syariah dengan menggunakan transaksi berbasis online. Pengembangan SOTS ini diharapkan dapat meningkatkan basis investor syariah di pasar modal dikarenakan sistem yang mudah dan nyaman. Pada akhir tahun 2016, terdapat 12 Anggota Bursa yang telah memiliki SOTS (Otoritas Jasa Keuangan, 2016: 34).

Pemanfaatan teknologi informasi dalam aktivitas perbankan pun sangat pesat. Layanan perbankan seperti sms banking, internet banking, hingga penggunaan uang elektronik (e-money) sudah menjadi bagian dari sistem perbankan Indonesia. selain itu, OJK telah menerapkan E-Lisencing Perbankan guna mempermudah proses perizinan serta mengurangi frekuensi korespondensi untuk mememnuhi kelengkapan persyaratan; membantu pihak internal untuk melakukan monitoring terhadap setiap tahapan perizinan dan mewujudkan transparansi proses perizinan bagi eksternal dan mempermudah penyampaian 
update informasi terkait perizinan perbankan. Aktivitas SJK berbasis teknologi yang terbaru adalah legitimasi financial technology (fin-tech) yang diatur dalam POJK No: 77/POJK.01/2016 tentang Pinjam Meminjam Uang Berbasis Teknologi Informasi.

\section{Implikasi perubahan tatanan sektor jasa keuangan global dan implementasi standar internasional terhadap penataan regulasi SJK}

a. Dominasi perbankan dalam SJK dan implikasinya terhadap model analisa risiko dalam pencegahan dan penanganan krisis sektor keuangan

Sektor Jasa Keuangan (SJK) Indonesia dapat dikategorikan ke dalam 3 kelompok besar yaitu sektor Perbankan, Pasar Modal dan Industri Keuangan Non Bank (IKNB), dan hingga saat ini sektor perbankan masih mendominasi SJK nasional dengan pangsa aset sekitar $78 \%$ dari total aset SJK. Kondisi ini tentu akan mempengaruhi kebijakan regulasi yang akan dikembangkan dalam SJK. Perbankan dianggap selalu memiliki keterkaitan dengan SJK lainnya, sehingga dalam perkembangan regulasinya, perbankan mendapatkan pengaturan yang dominan. Hal ini dapat ditemukan dalam Undang-undang Nomor 9 Tahun 2016 tentang Pencegahan dan Penanganan Krisis Sistem Keuangan (UU PPKSK), yang lebih menitikberatkan pada penanganan Bank Sistemik. Apabila dihubungkan dengan definisi sistem keuangan yang diatur dalam Pasal 1 angka 1 UU PPKSK, Sistem Keuangan adalah "sistem yang terdiri atas lembaga jasa keuangan, pasar keuangan, dan infrastruktur keuangan, termasuk sistem pembayaran, yang berinteraksi dalam memfasilitasi pengumpulan dana masyarakat dan pengalokasiannya untuk mendukung aktivitas perekonomian nasional". Selanjutnya, pengertian lembaga jasa keuangan berdasarkan Pasal 1 angka 4 Undang-undang Nomor 21 Tahun 2011 tentang Otoritas Jasa Keuangan (UU OJK) adalah: "lembaga yang melaksanakan kegiatan di sektor Perbankan, Pasar Modal, Perasuransian, Dana Pensiun, Lembaga Pembiayaan, dan Lembaga Jasa Keuangan lainnya”.

Mengacu pada ke dua pasal di atas, maka dapat disimpulkan bahwa elemen sistem keuangan meliputi ke 3 sektor yaitu Perbankan, Pasar Modal dan Industri Keuangan Non Bank (IKNB) yang meliputi lembaga pembiayaan dan lembaga jasa keuangan lainnya. Berdasarkan UU PPKSK, gangguan yang 
menular (contagion) merupakan gangguan yang berpotensi menimbulkan instabilitas pada sebagian maupun seluruh sistem keuangan, hal ini dikarenakan adanya interaksi dari faktor ukuran (size), kompleksitas usaha (complexity), keterkaitan antar isntitusi dan/atau pasar keuangan (interconnectedness), serta kecenderungan perilaku yang berlebihan dari pelaku institusi keuangan untuk mengikuti siktus perekonomian (procyclicality)

Berdasarkan UU PPKSK, Bank sebagai pihak yang memang menguasai peran penting dalam pembangunan nasional menjadi pintu masuk dalam hal terjadinya risiko sistemik. Hal in dapat difahami, mengingat sektor Pasar Modal dan IKNB dapat dipastikan melibatkan perbankan dalam aktivitasnya, apakah itu dalam posisi sebagai kreditor atau debitor, sehingga pencegahan dan penanganan risiko sistemik dalam sektor perbankan akan berdampak terhadap sektor lainnya. Dalam konteks perkembangan regulasi dan kebijakan SJK, terutama di tataran global, model pendekatan dengan bertumpu pada bank ini merupakan model pengawasan dengan menggunakan analisa interconnectedness, yaitu melalui koneksi atau keterkaitan antara bank dengan bank maupun unsur SJK lainnya atau bank lain yang beroperasi dalam sistem keuangan dan contagion effect, serta untuk dapat mengaitkan dampak risiko sistemik tersebut ke perekonomian dan loss confidence.

Berikut adalah ilustrasi mengenai interconnectedness di tataran global. Krisis keuangan di tahun 2008 sangat parah karena sejumlah besar bank, beroperasi di berbagai negara dan dipasar yang berbeda, semua mengalami kesulitan pada saat bersamaan. Ketika Lehman Brothers memengalami kegagalan pada 15 September 2008, terjadi penularaan secara cepat di seluruh sistem keuangan. Salah satu alasan utamanya adalah bahwa sistem keuangan global menjadi sangat saling terkait. Keterkaitan (interconnectedness) tidak selamanya buruk, karena transaksi antara pelaku pasar keuangan memungkinkan mereka memperoleh dana atau mentransfer risiko, tetapi dari segi stabilitas sistem keuangan, keterkaitan yang lebih besar antara bank akan meningkatkan kemungkinan distress akan menyebar lebih cepat ke seluruh sistem. Oleh karena itu interconnectedness (keterkaitan) merupakan penentu utama kecepatan dan 
kekuatan penularan. Misalnya, bank yang meminjamkan atau meminjam di pasar antar bank saling terkait, karena kegagalan satu bank dapat menyebabkan kerugian bagi pihak mitranya. Dalam sistem keuangan yang sangat saling terkait (highly interconnectedness), kemungkinan besar akan melihat tekanan atau kegagalan bank terjadi saat bersamaan, karena efek menular (contagion effect) semacam itu (Ziyun Liu, 2015: 2). Interconnectedness di sektor jasa keuangan ini penting bagi stabilitas keuangan, karena tekanan pada satu bagian atau sektor akan mempengaruhi atau menjalar ke sektor lainnya, sehingga akan mematikan fungsi sistem keuangan, dan apabila mempertimbangkan kemungkinan konskuensi dari penurunan kondisi makro ekonomi (keuangan), dampaknya akan lebih besar apabila tingkat interconnectedness lebih tinggi, baik langsung maupun tidak langsung. Berdasarkan alasan inilah, menurut Ziyun Liu (2015: 3), dikatakan bahwa interconnectedness merupakan faktor kunci kerangka kerja untuk menilai risiko sistemik di sektor perbankan yang dikembangkan oleh International Monetary Fund (IMF), Bank for International Settlement (BIS) dan Financial Stability Board (FSB).

Berdasarkan analisis penulis, tampaknya perkembangan regulasi SJK Indonesia mengadopsi model pendekatan ini untuk menganalisis risiko dalam pencegahan dan penanggulangan krisis keuangan yang dielaborasi dalam Pasalpasal UU PPKSK. Pada umumnya risiko yang terjadi, yaitu risiko sistemik yang mengakibatkan hilangnya value ekonomi atau hilangnya kepercayaan dan peningkatan ketidakpastian dalam sistem keuangan yang dapat menimbulkan efek negatif bagi perekonomian (Cicilia A. Harun, http://www.bi.go.id/id/publikasi/ occasional-paper/Documents/Kerangka-Pengukuran-Risiko-Sistemik.pdf, diakses tanggal 20 Agustus 2017).

b. Kepatuhan terhadap pedoman dan standar yang dikeluarkan oleh lembagalembaga internasional.

Arah pengembangan dan kebijakan sektor jasa keuangan Indonesia tidak dapat dilepaskan dari perubahan tatanan ekonomi dan reformasi keuangan global, termasuk ketika membuat regulasi dan kebijakan. Sebagai bagian dari sektor keuangan global, Indonesia aktif dalam lembaga-lembaga internasional yang 
diikuti baik oleh Bank Indonesia, Otoritas Jasa Keuangan maupun Pemerintah. Perkembangan regulasi sektor jasa keuangan tidak terlepas dari perkembangan kebijakan keuangan global, khususnya prinsip-prinsip dan standar internasional yang dikeluarkan oleh lembaga-lembaga internasional yang baik oleh OJK, Bank Indonesia maupun Pemerintah Indonesia. Penerapan prinsip-prinsip dan standar internasional dalam pengaturan sektor jasa keuangan ditempuh dengan tetap memperhatikan kemampuan sektor jasa keuangan dan kepentingan nasional, serta persiapan menghadapi persaingan global. Penerapan standar internasional ini mencakup beberapa hal (Otoritas Jasa Keuangan, 2016: 57), yaitu:

1) Struktur kepemilikan Lembaga Jasa Keuangan merupakan faktor utama dalam menentukan arah pengembangan dan daya saing lembaga jasa keuangan;

2) memperkuat penerapan standar internasional dalam hal pengaturan, pelaporan dan pengawasan sektor jasa keuangan;

3) mengembangkan tata kelola dan manajemen risiko yang sesuai dengan best practices;

4) memperkuat kesiapan menuju integrasi pasar keuangan ASEAN;

5) menyusun peraturan yang efektif untuk menciptakan kompetisi yang fair dan mencegah regulatory arbitrage;

6) pengaturan tentang remunerasi bagi pelaku di sektor jasa keuangan;

7) Meningkatkan efisiensi dan stabilisasi di sektor jasa keuangan; dan

8) memperkuat penanganan terhadap tindakan melawan hukum di bidang penghimpun dana masyarakat dan pengelolaan investasi.

Berikut beberapa lembaga internasional yang diikuti oleh OJK dan Bank Indonesia atau Bank Indonesia mewakili pemerintah Indonesia, yang erat kaitannya dengan perkembangan dan arah kebijakan SJK:

Tabel 1:

Lembaga Regional dan Internasional yang Diikuti Indonesia

\begin{tabular}{cll}
\hline No. Otoritas & Lembaga Internasional \\
\hline 1. Bank Indonesia (BI) & The South East Asian Central Bank Research \\
& and Training Centre (SEACEN). \\
& The South East Asian, Bew Zealand and Australia \\
& Forum Banking Supervision $($ SEANZA). \\
& The Execuitve Meeting of East Asian and Pasific \\
& Central Bank (EMEAP). \\
& ASEAN Central Bank Forum $(A C B F)$. \\
& Bank for International Settlement $(B I S)$. \\
& Financial Stability Board $(F S B)$ \\
\hline
\end{tabular}


Lanjutan Tabel 1:

\begin{tabular}{|c|c|c|}
\hline No. & Otoritas & Lembaga Internasional \\
\hline 2. & $\begin{array}{l}\text { Otoritas Jasa } \\
\text { Keuangan (OJK) }\end{array}$ & $\begin{array}{l}\text { International Capital Market Association (ICMA) } \\
\text { Ficonet International Financial Consumer } \\
\text { Protection Organisation } \\
\text { Islamic Financial Services Board (IFSB). } \\
\text { The ASEAN Insurance Training and Research } \\
\text { Institute (AITRI) } \\
\text { International Organisation of Securities } \\
\text { Commissions (IOSCO) } \\
\text { International Financial Reporting Standards } \\
\text { (IFRS) } \\
\text { Financial Stability Board Supervisory and } \\
\text { Regulatory (FSB SRC) \& FSB Regional } \\
\text { Consultataive Group (RCG) } \\
\text { International Accounting Standard Board (IASB). } \\
\text { Executives Meeting of East Asia Pasific Central } \\
\text { Banks (EMEAP) } \\
\text { Basel Committee on Banking Supervision (BCBS) }\end{array}$ \\
\hline 3. & $\begin{array}{l}\text { Bank Indonesia } \\
\text { mewakili Pemerintah } \\
\text { Indonesia }\end{array}$ & $\begin{array}{l}\text { Association of South East Asian Nations } \\
\text { (ASEAN) } \\
\text { ASEAN + Cina, Jepang dan Korea (ASEAN +3) } \\
\text { Asean Development Bank (ADB) } \\
\text { Asia Pasifif Economic Cooperation (APEC) } \\
\text { Asia Europe Meeting (ASEM) } \\
\text { Islamic Development Bank } \\
\text { International Monetary Fund (IMF) } \\
\text { World Bank, termasuk keanggotaan di } \\
\text { International Bank of Reconstruction and } \\
\text { Development (IBRD); International Development } \\
\text { Association (IDA) dan International Finance } \\
\text { Cooperation (IFC) serta Multilateral Investment } \\
\text { Guarantee Agency (MIGA). } \\
\text { World Trade Organization (WTO) } \\
\text { Intergovernmental Group of } 20 \text { (G-20) } \\
\text { Intergovernmental Group of } 15 \text { (G-15 sebagai } \\
\text { observer) } \\
\text { Intergovernmental Group of } 24 \text { (G-24 sebagai } \\
\text { observer) }\end{array}$ \\
\hline
\end{tabular}

Sumber: Bank Indonesia dan OJK 
Keikutsertaan Bank Indonesia/OJK dan pemerintah Indonesia dalam lembaga-lembaga internasional di atas, diperlukan untuk menunjang pelaksanaan tugas Bank Indonesia, OJK dan Pemerintah yang berhubungan dengan ekonomimoneter, maupun perbankan sebagai bagian dari SJK. Keikutsertaan Indonesia dalam lembaga-lembaga internasional tersebut mempengaruhi regulasi dan kebijakan SJK Indonesia. Berbagai standar dan pedoman yang dikeluarkan oleh lembaga-lembaga internasional harus dipatuhi oleh otoritas ketika membuat regulasi atau mengambil kebijakan. Implementasi standar internasional yang diadopsi dalam regulasi SJK antara lain adalah pendekatan sistem pengawasan Bank yang digunakan oleh OJK. Saat ini, OJK melaksanakan sistem pengawasan dengan menggunakan 2 (dua) pendekatan (Otoritas Jasa Keuangan, 2016: 26), yaitu:

1) Pengawasan berdasarkan kepatuhan (Compliance Based Supervision/CBS), yaitu pantauan kepatuhan bank terhadap ketentuan-ketentuan yang terkait dengan operasi dan pengelolaan bank dengan tujuan memastikan bahwa bank dikelola secara baik dan benar menurut prinsip kehati-hatian. Pengawasan terhadap pemenuhan aspek kepatuhan merupakan bagian yang tidak terpisahkan dari pelaksanaan pengawasan bank berdasarkan risiko.

2) Pengawasan berdasarkan risiko (Risk Based Supervision/RBS), yaitu pengawasan bank yang menggunakan strategi dan metodologi berdasarkan risiko yang memungkinkan pengawas bank dapat mendeteksi risiko signifikan secara dini dan mengambil tindakan pengawasan yang sesuai dan tepat waktu.

Ke dua jenis sistem pengawasan di atas merupakan standar internasional yang dikeluarkan oleh Basel Committee on Banking Supervision (BCBS), yang dikenal dengan Basel II sebagai upaya peningkatan manajemen risiko bank, sehingga melalui implementasi Basel II bank dapat memperoleh insentif dan sejalan dengan itu menjamin kestabilan sistem keuangan yang pada akhirnya akan mendukung pertumbuhan ekonomi (Direktorat Penelitian dan Pengaturan Perbankan, 2006: 3). Basel Committee on Banking Supervision (BCBS) adalah Komite Otoritas Pengawas Perbankan yang didirikan oleh Gubernur Bank Sentral dari Kelompok G-10. Tujuannya untuk meningkatkan pemahaman akan isu-isu pengawasan utama dan meningkatkan kualitas pengawasan perbankan di seluruh dunia, dan Sekretariat Komite ditempatkan di Bank for Insternational Settlement $(B I S)$ di Basel Swiss. 
Khusus untuk pengembangan regulasi dan kebijakan sektor perbankan, mengacu kepada pendapat Mochtar Kusumaatmadja (2002: 24), pembaruan hukum lebih memungkinkan dilaksanakan pada bidang-bidang hukum yang bersifat netral seperti perbankan, karena penggunaan model-model asing tidak akan menimbulkan suatu kesulitan. Oleh karena itu, salah satu upaya pembaruan hukum perbankan adalah perbaikan dan perubahan undang-undang perbankan melalui proses adopsi dan adaptasi dengan memperhatikan beberapa ketentuan yang berasal dari organisasi internasional maupun regional.

Terkait sektor jasa keuangan dan Indonesia menjadi salah satu negara participant berkomitmen untuk menerapkan Basel Regulatory Framework sesuai dengan tenggat waktu yang ditentukan, tetapi tetap memperhatikan kondisi lokal dan dinamika industri perbankan nasional agar adopsi pengaturan yang dilakukan berkontribusi optimal terhadap kinerja perbankan. Kerangka Basel III: Global Regulatory Framework for more Resilient Banks and Banking Systems dipublikasikan pada akhir 2010 yang merupakan penyempurnaan dari kerangka Basel II. Adapun substansi Basel III mencakup area sebagaimana dijelaskan pada berikut:

Tabel 2:

Substansi Basel III

\begin{tabular}{|c|c|c|}
\hline No. & Substansi & Area \\
\hline 1. & $\begin{array}{l}\text { Penguatan kerangka } \\
\text { permodalan global }\end{array}$ & $\begin{array}{l}\text { a. Meningkatkan kualitas, konsistensi, dan } \\
\text { transparansi permodalan } \\
\text { b. Mengembangkan cakupan risiko } \\
\text { c. Tambahan persyaratan modal berbasis risiko } \\
\text { dengan leverage ratio } \\
\text { d. Mengurangi procyclicality dan meningkatkan } \\
\text { countercyclical buffer addressing systemic } \\
\text { risk dan keterkaitan antar lembaga keuangan }\end{array}$ \\
\hline 2 & $\begin{array}{l}\text { Pengenalan standar } \\
\text { likuiditas global }\end{array}$ & $\begin{array}{l}\text { a. Liquidity Coverage Ratio }(L C R) \\
\text { b. Net Stable Funding Ratio }(N S F R) \\
\text { c. Monitoring Tools }\end{array}$ \\
\hline
\end{tabular}

Sumber: Bank Indonesia, 2012. 
Berdasarkan substansi diatas, Basel III secara mendasar menyajikan reformasi yang dilakukan oleh BCBS untuk memperkuat permodalan dan standar likuiditas dengan tujuan untuk meningkatkan ketahanan sektor perbankan terhadap krisis. Kemampuan sektor perbankan menyerap shock yang terjadi karena tekanan keuangan dan perekonomian diharapkan dapat mengurangi penyebaran risiko dari sektor keuangan terhadap perekonomian. Penerapan Basel III di Indonesia diberikan waktu persiapan hingga awal 2019 mendatang. Penerapan kerangka aturan tersebut dilakukan secara bertahap, dan dengan diterapkannya Basel III, perbankan nasional diharapkan akan melakukan kegiatan bisnisnya secara hati-hati dan tidak menimbulkan risiko tinggi agar dapat terhindar dari krisis finansial yang mungkin akan terjadi di masa yang akan datang. Target dari implementasi secara penuh dan utuh Basel III direncanakan pada tahun 2018. Dengan demikian ada periode transisi yang masih cukup panjang. Aturan Basel III ini akan membuat permodalan perbankan menjadi lebih kuat karena Basel III mewajibkan bank untuk menaikan kualitas permodalan sebesar tujuh persen $(7 \%)$ atas risiko aset-aset mereka yang dinilai naik dari tahun-tahun sebelumnya yaitu $2 \%$.

Di tingkat regional, SJK Indonesia dihadapkan pada kesepakatan ASEAN untuk membentuk masyarakat ekonomi ASEAN, yang selanjutnya dimulai dengan integrasi keuangan ASEAN, antara lain dengan di bidang pasar modal dengan menyepakati The ASEAN Capital Market Infrastructure (ACMI), dan perbankan melalui kesepakatan ASEAN Banking Integration Framework (ABIF), yang bertujuan untuk mencapai liberalisasi sektor perbankan pada tahun 2020 . Implementasi ABIF yang bertumpu pada prinsip resiprocal (kesetaraan) dan reducing gap (pengurangan kesenjangan) memberikan peluang bagi perbankan Indonesia yang memenuhi kriteria sebagai Qualified Asean Bank (QAB) untuk memasuki pasar di negara-negara ASEAN. Oleh karena itu, perbankan nasional didorong untuk memenuhi kriteria $Q A B$, agar dapat memperluas pangsa pasar ke negara-negara ASEAN (Tri Handayani dan Lastuti Abubakar, 2016: 157). Bank Indonesia telah menyepakati kriteria umum bank yang masuk dalam kategori Qualified Asean Bank ( $Q A B)$ atau bank-bank yang memiliki kualifikasi untuk 
berkekspansi ke kawasan ASEAN. Kriteria dimaksud adalah: (1) dikelola dengan baik (well managed); (2) memiliki cukup modal (well capitalised); (3) Bank mendapatkan rekomendasi dari Otoritas (recommended by authorities); (4) Lulus ketentuan Basel; (5) merupakan Bank yang dinilai penting di negara asalnya (Tri Handayani dan Lastuti Abubakar, 2016: 157). Mengacu pada pesatnya perubahan tatanan SJK Indonesia, maka perkembangan regulasi SJK dan regulasi yang berkaitan dengan SJK, tentu wajib mengikuti dan mematuhi kesepakatan, prinsipprinsip ataupun standar yang ditentukan oleh lembaga-lembaga internasional yang diikuti oleh Indonesia.

\section{Perkembangan regulasi sektor jasa keuangan}

Regulasi sektor jasa keuangan merupakan regulasi yang ketat (heavily regulated), mengingat sektor jasa keuangan menjalankan kegiatan usaha dengan menggunakan dana pihak ketiga. Oleh karena itu, prinsip utama dalam aktivitas sektor jasa keuangan, khususnya perbankan mengedepankan prinsip kehati-hatian (prudential principle) sebagai prinsip utama. Prinsip ini memastikan bahwa lembaga jasa keuangan mentaati seluruh regulasi baik peraturan perundangundangan maupun kebijakan yang dituangkan dalam bentuk pedoman bagi penyelenggara sektor jasa keuangan (Lastuti Abubakar dan Tri Handayani, 2017). Khusus untuk Pasar Modal, prinsip utama yang melandasi kegiatan di pasar modal khususnya transaksi perdagangan di Bursa adalah prinsip transparansi (full disclosure). Ke dua prinsip ini dan prinsip-prinsip lainnya, tersirat dalam regulasi dan kebijakan SJK Indonesia. Seiring dengan perkembangan keuangan global dan regional, regulasi SJK pun mengalami perkembangan yang pesat meliputi beberapa aspek, antara lain:

a. Dualisme sistem hukum ekonomi

Tatanan hukum ekonomi Indonesia mengalami perubahan yang signifikan seiring dengan perubahan tatanan ekonomi global. Krisis keuangan global telah menyebabkan terjadinya transformasi sistem hukum ekonomi, dari sistem konvensional ke arah sistem hukum ekonomi Islam. Hal ini berdampak pula terhadap tatanan hukum ekonomi Indonesia, dengan diberlakukannya hukum ekonomi Islam sehingga terjadi dualisme hukum ekonomi, yaitu berlakunya lebih 
dari satu sistem hukum yang mengatur bidang yang sama, yaitu hukum ekonomi konvensional dan hukum ekonomi Islam secara berdampingan. Hal ini dapat dilihat dengan diterbitkannya Undang-undang Nomor 21 Tahun 2008 tentang Perbankan Syariah. Sejak diinisiasi tahun 1992, pertumbuhan ekonomi syariah di Indonesia menunjukkan grafik meningkat.

Pada tahun 2016, jumlah Bank Umum Syariah mencapai 13 Bank Umum, 22 Unit Usaha Syariah dan 165 BPR Syariah (Departemen Perbankan Syariah, 2016: 12). Demikian juga dengan pertumbuhan asuransi syariah, yang hingga tahun 2016 berjumlah 55 perusahaan terdiri dari Perusahaan Asuransi Jiwa Syariah, Perusahaan Asuransi Umum Syariah, Unit Syariah Perusahaan Asuransi Umum dan Unit Syariah Perusahaan Reasuransi (Asosiasi Asuransi Syariah Indonesia, 2016). Ketentuan umum tentang asuransi syariah masih merupakan bagian dari Undang-undang Nomor 40 Tahun 2014 tentang Perasuransian. Bukan tidak mungkin, Asuransi Syariah akan memiliki undang-undang tersendiri di masa yang akan datang. Demikian juga halnya dengan industri keuangan non bank syariah dan pasar modal syariah, yang regulasinya masih berupa peraturan Otoritas Jasa Keuangan.

Pemerintah dan OJK telah menerbitkan pedoman umum dalam bentuk masterplan dan roadmap untuk pengembangan SJK Syariah di Indonesia, berdampingan dengan SJK konvensional, yang terdiri atas: Masterplan Arsitektur Keuangan Syariah Indonesia (Masterplan AKSI) yang diterbitkan oleh BAPPENAS, Roadmap Perbankan Syariah Indonesia 2015-2019, Roadmap Pasar Modal Syariah 2015-2019, Roadmap IKNB Syariah 2015-2019. Dasar hukum yang digunakan oleh OJK dalam membentuk regulasi SJK didasarkan pada Fatwa Dewan Syariah Nasional (DSN)-Majelis Ulama Indonesia (MUI), yang hingga Februari 2017 berjumlah 109 Fatwa, yang secara lebih lengkap dapat dilihat pada tabel berikut: 
Tabel 3:

\section{Data Fatwa DSN di Bidang Ekonomi Syariah}

\begin{tabular}{|c|c|c|c|}
\hline No. & Jumlah & Bidang & Keterangan \\
\hline 1. & 27 & Hukum Perbankan & \multirow{5}{*}{$\begin{array}{l}\text { Fatwa DSN-MUI ini selanjutnya } \\
\text { diberlakukan dan dimasukkan } \\
\text { dalam PBI dan POJK. }\end{array}$} \\
\hline 2. & 16 & Hukum Pasar Modal & \\
\hline 3. & 10 & Industri Keuangan Syariah & \\
\hline 4. & 7 & Bisnis & \\
\hline 5. & 45 & Umum & \\
\hline 6. & 9 & Fatwa baru & Disosialisasikan \\
\hline
\end{tabular}

Sumber: Dewan Syariah Nasional, 2017.

Dalam waktu dekat, akan diluncurkan lembaga baru di bawah DSN-MUI yang bertugas melakukan sertifikasi pengawas syariah, yaitu Lembaga Sertifikasi Profesi Pengawas Syariah. lembaga ini dibentuk untuk meningkatkan kompetensi dan keahlian Dewan Pengawas Syariah sebagai organ dari DSN-MUI dalam melakukan pengawasan syariah di lembaga Keuangan Syariah, Lembaga Bisnis Syariah dan Lembaga Perekonomian Syariah (Dewan Syariah Nasional-MUI, https://dsnmui.or.id/sambutan-ketua-dsn-mui-dalam-sosialisasi-fatwa-fatwa-dsnmui-21-maret-2017).

b. Kerjasama otoritas dan pengawasan terintegrasi

Perkembangan regulasi di SJK Indonesia terlihat dari perubahan otoritas yang melakukan pengawasan SJK, dimana seluruh pengawasan SJK menjadi tugas OJK sejak diberlakukannya Undang-undang Nomor 21 Tahun 2011 tentang Otoritas Jasa Keuangan (UU OJK). Pengawasan sektor perbankan yang semula dilakukan oleh Bank Indensia beralih ke OJK. Dengan demikian, terdapat 2 otoritas di sektor Jasa Keuangan, yaitu Bank Indonesia sebagai otoritas moneter dan OJK sebagai otoritas jasa keuangan yang mempunyai fungsi, tugas dan wewenang pengaturan, pengawasan, pemeriksaan dan penyidikan di sektor jasa keuangan sebagaimana dimaksud dalam UU OJK. Selanjutnya, Pasal 5 UU OJK mengamanatkan OJK untuk menyelenggarakan sistem pengaturan dan pengawasan terintegrasi terhadap keseluruhan kegiatan di dalam SJK. Perkembangan Sektor keuangan menuntut OJK untuk melakukan pengawasan atas lembaga jasa keuangan secara terintegrasi antar sub sektor keuangan. Dengan demikian 
lembaga jasa keuangan yang melaksanakan kegiatan di sektor perbankan, perusahaan asuransi dan reasuransi, perusahaan efek dan/atau perusahaan pembiayaan, yang tergabung dalam satu konglomerasi keuangan, selain harus menerapkan ketentuan yang berlaku bagi masing-masing sektor juga harus menerapkan ketentuan untuk konglomerasi keuangan yang diterbitkan oleh OJK dalam rangka pengawasan terintegrasi.

c. Perkembangan jenis perjanjian tidak bernama di SJK Indonesia

Sektor Jasa Keuangan, khususnya perbankan dan pasar modal banyak mengembangkan produk dan layanan, yang berkaitan dengan perjanjian, khususnya perjanjian tidak bernama yang tunduk pada ketentuan Buku III KUHPerdata. Perkembangan perjanjian di SJK ini banyak dipengaruhi oleh transaksi common law system, sehingga masih memerlukan penyesuaian dalam implementasinya. Beberapa perjanjian tidak bernama yang berkembang dalam praktik SJK Indonesia, antara lain dapat dilihat pada tabel berikut:

Tabel 4:

Perjanjian yang Berkembang di SJK Indonesia

\begin{tabular}{cll}
\hline No. Sektor & Nama Perjanjian & Keterangan \\
\hline 1. Perbankan & Perjanjian Perwaliamanatan & Perjanjian trust dan \\
& Perjanjian Trust & hedging diatur dalam \\
& Transaksi Derivatif & PBI, sedangkan \\
& Transaksi Hedging (Lindung & perwaliamanatan dan \\
& Nilai) & Anjak Piutang \\
& Perjanjian Anjak Piutang & mengacu pada UU \\
& & Perbankan. \\
\hline 2. Pasar Modal & Perjanjian Kepialangan & Perjanjian yang \\
& Kontrak Investasi Kolektif & berkembang dalam \\
& Perjanjian Mitra Pengimbang & praktik Pasar Modal \\
& (Counter Party) & mengacu pada UU \\
& Transaksi derivatif & Pasar Modal dan \\
& Scripless Trading System & POJK/Peraturan \\
& Sistem Online Trading Syariah & Bapepam-LK. \\
\hline Perjanjian Leasing & Dalam UU tentang \\
& Perjanjian Modal Ventura & Lembaga \\
& Perjanjian Anjak Piutang & Pembiayaan dan \\
& Perjanjian Kepialangan/Keagenan & POJK. \\
& (Asuransi) & \\
& Perjanjian penjaminan & \\
\hline
\end{tabular}


Lanjutan Tabel 4:

\begin{tabular}{rll}
\hline No. Sektor & Nama Perjanjian & Keterangan \\
\hline 4. SJK Syariah & $\begin{array}{l}\text { Akad-akad Syariah, khususnya } \\
\text { akad campuran (hybrid contract) } \\
\text { baik di perbankan syariah, pasar } \\
\end{array}$ & $\begin{array}{l}\text { Mengacu pada UU } \\
\text { modal syariah dan IKNB Syariah. } \\
\text { dan POJK. }\end{array}$ \\
\hline
\end{tabular}

Sumber: Diolah oleh Penulis.

Perkembangan perjanjian di SJK Indonesia merupakan tuntutan sektor jasa keuangan, yang sebagian besar mengacu pada praktik sektor jasa keuangan global. Perbankan dan pasar modal misalnya, mengembangkan perjanjian tidak bernama sebagai bagian dari prinsip dan standar keuangan global, sehingga diperlukan keberadaannya. Permasalahan hukum yang sering muncul adalah adanya benturan sistem hukum antara sistem hukum yang mempengaruhi sistem hukum perjanjian Indonesia dengan sistem hukum perjanjian yang berasal dari common law system. Walaupun sistem hukum perjanjian dalam Buku III bersifat terbuka (Pasal 1319 KUHPerdata) dan menganut asas kebebasan berkontrak (Pasal 1338 ayat 1 KUHPerdata), tetapi tidak selalu dapat diimplementasikan dengan sempurna. Sebagai contoh, perjanjian trust di perbankan akan berhadapan dengan dual ownership terhadap satu aset (Lastuti Abubakar, 2009: 38-39), yang tidak dikenal dalam hukum benda Indonesia, sehingga diperlukan penyesuaian dalam klausulklausul kontraknya. Demikian halnya dengan transaksi derivatif di pasar modal, akan berhadapan dengan konsep benda menurut Buku II KUHPerdata, yang bersifat tertutup sehingga diperlukan perluasan dalam pengertian benda yang berpotensi menimbulkan "dispute", apabila tidak diatur secara tegas dan baik. Pembaruan hukum perdata merupakan keharusan untuk mengantisipasi perkembangan transaksi dan produk di SJK Indonesia. Model pembaruan hukum Perdata Indonesia dapat mengacu pada model pembaruan Niew Burgerlijk Wetboek (NBW) di Belanda, yang sudah mengantisipasi perkembangan perbankan dan pasar modalnya dengan baik, dengan mengubah konsep benda. 
d. Perkembangan surat berharga sebagai benda dalam SJK Indonesia

Selain mengembangkan jenis-jenis perjanjian tidak bernama, SJK Indonesia khususnya pasar modal, mengembangkan instrumen surat berharga, yang dikenal dengan instrumen derivatif, yang beragam sifatnya. Secara umum, surat berharga pasar modal dan perbankan dapat dikelompokkan menjadi 2, yaitu debt isntrument (instrumen utang), seperti obligasi, surat sanggup, dan promissory notes dan equity instrument (instrumen penyertaan), seperti saham. Dalam perkembangannya, surat berharga di SJK Indonesia berkembang sangat pesat, yang dikenal dengan nama instrumen derivatif antara lain Waran, Right Issue, Assets Backed Securities, Option, Real Estate Investment trust (REITs) atau Dana Investasi Real Estate (DIRE), dan Futures LQ 45 (Kontrak Berjangka Indeks Efek). Keseluruhan jenis derivatif tersebut diturunkan dari efek acuannya apakah itu saham atau obligasi sebagai underlying assets. Selain surat berharga yang diperdagangkan di pasar modal konvensional, pasar modal syariah juga menawarkan Sukuk (Surat Berharga Syariah) yang sangat berbeda dengan surat berharga konvensional. Permasalahan hukum yang timbul adalah pengembangan jenis surat berharga baik di pasar modal maupun perbankan tersebut memerlukan landasan hukum yang kokoh untuk memberikan perlindungan dan kepastian hukum bagi investor. Regulasi di SJK sudah mengatur dalam PBI dan POJK (dulu Peraturan Bapepam-LK), tetapi ketentuan umum yang mengatur hukum Benda dan Hukum Perjanjian di Indonesia masih mengacu pada KUHPerdata. Oleh karena itu, perkembangan SJK Indonesia perlu diikuti dengan pembaruan Hukum Perdata.

e. Mekanisme penyelesaian sengketa di SJK Indonesia

Penyelesaian sengketa sektor jasa keuangan, khususnya sektor perbankan memegang peran penting dalam memberikan perlindungan konsumen SJK. Perlindungan konsumen SJK merupakan rangkaian kebijakan, yang antara lain menfasilitasi penyelesaian sengketa bagi konsumen SJK dan masyarakat pengguna jasa keuangan. Berdasarkan POJK Nomor: 1/POJK.07/2013 tentang Perlindungan Konsumen Sektor Jasa Keuangan, maka konsumen dapat menempuh 2 tahapan penyelesaian pengaduan SJK, yaitu penyelesaian pengaduan yang dilakukan oleh Lembaga Jasa Keuangan (Internal Dispute Resolution) dan 
penyelesaian sengketa melalui lembaga peradilan atau lembaga di luar pengadilan (External Dispute Resolution). Penyelesaian Pengaduan oleh Lembaga Jasa Keuangan (LJK) dilakukan berdasarkan asas musyawarah untuk mufakat, yang tidak selalu tercapai, sehingga diperlukan mekanisme penyelesaian sengketa antara Konsumen dengan LJK melalui lembaga peradilan atau di luar peradilan.

Mengingat SJK memiliki peran penting dalam suatu negara, yaitu sebagai lembaga kepercayaan (agent of trust) baik dalam menghimpun dana maupun menyalurkan dana, sebagai agen pembangunan Negara (agent of development) dan sebagai pemberi layanan (Otoritas Jasa Keuangan, 2016: 4), maka diperlukan penyelesaian sengketa yang cepat, efisien dan berorientasi win-win solution. Penyelesaian sengketa yang digunakan harus dapat menjaga kepercayaan investor dan konsumen dalam setiap aktivitas dan kegiatan usaha SJK (market confidence), dan memberikan peluang dan kesempatan untuk perkembangan bagi Pelaku Usaha Jasa Keuangan secara adil, transparan dan efisien. Penyelesaian sengketa perbankan yang berlarut-larut misalnya, dapat merugikan nasabah dan meningkatkan risiko reputasi bagi bank. Selama ini penyelesaian pengaduan nasabah oleh Bank tidak selalu memuaskan nasabah dan berpotensi menimbulkan sengketa di bidang perbankan antara nasabah dengan bank. Penyelesaian sengketa perbankan antara nasabah dengan Bank dapat dilakukan secara sederhana, murah, dan cepat melalui cara mediasi. Berdasarkan pertimbangan tersebut, Bank Indonesia menerbitkan PBI Nomor: 8/5/PBI/2006 tentang Mediasi Perbankan. Selanjutnya, penyelesaian sengketa di SJK tampaknya diarahkan kepada penyelesaian sengketa di luar pengadilan, walaupun tidak tertutup kemungkinan menyelesaikan sengketa SJK ke jalur litigasi melalui Pengadilan. Hal ini dapat dilihat dari berlakunya POJK Nomor: 1/POJK.07/2014 tentang Alternatif Penyelesaian Sengketa (LAPS) di Sektor Jasa Keuangan, yang memungkinkan sengketa diselesaikan melalui layanan penyelesaian sengketa mediasi, ajudikasi dan arbitrase.

Penyelesaian sengketa dapat diselesaikan baik di dalam pengadilan maupun di luar pengadilan. Merujuk pada Undang-undang Nomor 21 Tahun 2008 tentang Perbankan Syariah, maka yang dimaksud Pengadilan, termasuk Pengadilan Agama untuk penyelesaian perbankan syariah. Demikian halnya 
dengan Arbitrase, termasuk ke dalamnya Badan Arbitrase Syariah Nasional (BASYARNAS). Berdasarkan data yang dikeluarkan oleh OJK, berikut LAPS yang sudah terdaftar di OJK dan kasus yang sudah ditangani.

Tabel 5:

Daftar LAPS Terdaftar di OJK dan Kasus di Semester 1 Tahun 2016

\begin{tabular}{clc}
\hline No. & Lembaga Alternatif Penyelesaian Sengketa & $\begin{array}{c}\text { Jumlah } \\
\text { Kasus }\end{array}$ \\
\hline 1. & Badan Mediasi dan Arbitrase Asuransi Indonesia (BMAI) & 28 \\
\hline 2. & Badan Arbitrase Pasar Modal Indonesia (BAPMI) & 9 \\
\hline 3. & Badan Mediasi Dana Pensiun (BMDP) & 1 \\
\hline 4. & Lembaga Alternatif Penyelesaian Sengketa Perbankan & 9 \\
& Indonesia (LAPSPI) & - \\
\hline 5. & $\begin{array}{l}\text { Badan Arbitrase dan Mediasi Perusahaan Penjaminan } \\
\text { Indonesia (BAMPPI) }\end{array}$ & - \\
\hline 6. & $\begin{array}{l}\text { Badan Mediasi Pembiayaan dan Pegadaian Indonesia } \\
\text { (BMPPI) }\end{array}$ \\
\hline
\end{tabular}

Sumber: Otoritas Jasa Keuangan

Berdasarkan data di atas, dapat dilihat bahwa sengketa perdata SJK masih terbilang sedikit dan jarang, tetapi demikian kesiapan LPAS merupakan salah satu upaya untuk memberikan perlindungan dan kepastian hukum yang optimal untuk mendorong perkembangan SJK dalam rangka percepatan pertumbuhan ekonomi nasional.

\section{Simpulan dan Saran}

\section{Simpulan}

a. Ditengah siklus pertumbuhan ekonomi yang melambat serta situasi global yang kurang menggembirakan, sektor jasa keuangan dapat memainkan peranan penting untuk mempercepat pertumbuhan ekonomi. Apabila dimanfaatkan secara optimal, sektor jasa keuangan dapat meningkatkan kapasitas perekonomian, sehingga tercapai pertumbuhan yang lebih tinggi dan lebih berkualitas. Pertumbuhan ekonomi yang lebih tinggi merupakan keharusan agar dapat menyerap tambahan tenaga kerja dan meningkatkan taraf hidup masyarakat. 
b. Sektor Jasa Keuangan diarahkan untuk semakin kontributif dalam mendorong kegiatan ekonomi masyarakat; memiliki daya tahan yang memadai dalam mengantisipasi goncangan yang dapat muncul dari lingkungan domestik maupun eksternal. Selain itu SJK diarahkan untuk dapat mengambil peran dalam mewujudkan kemandirian finansial masyarakat melalui program keuangan yang inklusif.

c. Untuk dapat berperan dalam mempercepat pertumbuhan ekonomi nasional, SJK memerlukan dukungan regulasi yang mampu mengantisipasi perkembangan SJK baik regional mapun global. Beberapa perkembangan hukum SJK dapat dilihat dalam regulasi kelembagaan dan pengawasan terintegrasi; perkembangan regulasi yang berkaitan dengan layanan dan produk, serta proses penyelesaian sengketa. Khusus di bidang perbankan, regulasi perbankan diarahkan untuk mendorong perbankan Indonesia untuk memanfaatkan ASEAN Banking Integration Framework (ABIF) guna memperluas akses pasar ke negara-negara ASEAN.

\section{Saran}

a. Diperlukan literasi sektor keuangan yang berkelanjutan bagi masyarakat untuk meningkatkan kepercayaan dan kebutuhan terhadap SJK.

b. Peningkatan kuantitas dan kualitas SDM di sektor jasa keuangan melalui prgram sertifikasi untuk menjamin kompetensi dan profesionalisme.

c. Diperlukan pembaruan hukum yang mendukung aktivitas SJK, khususnya hukum Perdata dan hukum Perbankan sebagai landasan hukum yang kokoh bagi pengembangan SJK dalam mendorong pertumbuhan ekonomi. 


\section{DAFTAR PUSTAKA}

\section{Buku:}

Bank Indonesia. 2012. Consultative Paper Basel III: Global Regulatory Framework For More Resilient Banks And Banking System. Jakarta: Departemen Penelitian dan Pengaturan Perbankan Bank Indonesia.

Departemen Perbankan Syariah. 2016. Roadmap Perbankan Syariah 2015-2019. Jakarta: Otoritas Jasa Keuangan.

Direktorat Penelitian dan Pengaturan Perbankan. 2006. Implementasi Basel II di Indonesia. Jakarta: Bank Indonesia.

Mochtar Kusumaatmadja. 2002. Konsep-konsep hukum dalam Pembangunan; Kumpulan Karya Tulis. Bandung: Alumni.

Otoritas Jasa Keuangan. 2016. Booklet Perbankan Indonesia 2016. Jakarta: OJK.

Otoritas Jasa Keuangan. 2016. Master Plan Sektor Jasa Keuangan Indonesia2015-2019. Jakarta: OJK.

Otoritas Jasa Keuangan. 2016. Pasar Modal Syariah-Sinergi Menuju Pasar Modal Syariah yang Lebih Besar dan Berkembang. Jakarta: OJK.

Otoritas Jasa Keuangan. 2016. Perbankan-Seri Literasi Keuangan Perguruan Tinggi. Jakarta: OJK \& Industri Jasa Keuangan.

\section{Paraturan perundang-undangan:}

Peraturan Otoritas Jasa Keuangan Nomor: 1/POJK.07/2013 tentang Perlindungan Konsumen Sektor Jasa Keuangan.

Peraturan Otoritas Jasa Keuangan Nomor: 1/POJK.07/2014 tentang Lembaga Alternatif Penyelesaian Sengketa Sektor Jasa Keuangan.

Peraturan Bank Indonesia Nomor: 8/5/PBI/2006 tentang Mediasi Perbankan.

\section{Jurnal/Laporan:}

Asosiasi Asuransi Syariah Indonesia. 2016. Data Bisnis Asuransi dan Re-asuransi Syariah Q1.

Bank Indonesia. 2015. Laporan Perekonomian Indonesia. Jakarta.

Bank Indonesia. 2016. "Tantangan, Arah Kebijakan dan Prospek Perekonomian Indonesia”. Laporan Perekonomian Indonesia 2015-Bagian IV. Jakarta. 
Dewan Syariah Nasional-MUI. 2017. Kata Sambutan Ketua DSN-MUI dalam Acara Sosialisasi Fatwa-Fatwa DSN-MUI.

Lastuti dan Tri Handayani. 2017. "Telaah Yuridis terhadap Prinsip Kehati-hatian Bank dalam Aktivitas Perbankan”. Jurnal De Lega Lata.Volume 2. Nomor 1. Januari-Juni.

Tri Handayani dan Lastuti Abubakar. 2016. "Implikasi Kesepakatan Asean Banking Integration Framework (ABIF) terhadap Pembaruan Hukum Perbankan Indonesia”. Jurnal Rechtidee. Volume 11. Nomor 2.

\section{Internet:}

BI.go.id. http://www.bi.go.id/id/perbankan/implementasibasel/consultativepapers/ Documents/9bf8e496156149f1a9bfdcc31e9758bepublishedCPB3.pdf.

Cicilia A Harun, "Occasional Paper: Kerangka Pengukuran Risiko Sistemik, http://www.bi.go.id/id/publikasi/occasional-paper/Documents/KerangkaPengukuran-Risiko-Sistemik.pdf

MUI.or.id. https://dsnmui.or.id/sambutan-ketua-dsn-mui-dalam-sosialisasi-fatwafatwa-dsn-mui-21-maret-2017.

Warta Ekonomi. http://wartaekonomi.co.id/read131654/tumbuh-pesat-kontribusisektor-keuangan-meningkat-terhadap-pdb.html

Ziyun Liu, Stephanie Quiet, Benedith Roth, Banking Sector Interconnectedness: What is it, How Can We Measure it and why does it Matter?, Quarterly Bulletin 2015 Q2. 


\section{BIODATA PENULIS}

$\begin{array}{ll}\text { Nama } & \text { : Tri Handayani, S.H., M.H } \\ \text { Pekerjaan } & : \text { Dosen } \\ \text { Jabatan } & \text { : Lektor } \\ \text { Nomor HP } & : 081313407048 \\ \text { E-mail } & \text { : tri.handayani@ unpad.ac.id } \\ \text { Alamat Kantor } & \text { : Jl. Dipati Ukur No. 35, Bandung }\end{array}$

$\begin{array}{ll}\text { Nama } & \text { : Dr. Lastuti Abubakar, S.H., M.H } \\ \text { Pekerjaan } & : \text { Dosen } \\ \text { Jabatan } & : \text { Lektor Kepala } \\ \text { Nomor HP } & : 08122150155 \\ \text { E-mail } & : \text { lastuti.abubakar@unpad.ac.id } \\ \text { Alamat Kantor } & : \text { Jl. Dipati Ukur No. 35, Bandung }\end{array}$

